\title{
Effect of Foliar spraying with Yeast Extract and Hydrogen Peroxide on Yield and Quality of Sweet Potato
}

\author{
Abo EL-Fadl, N.I.; Dina, S. EL-Mesirry and Hebatulla, M. Rady \\ Sabaheya Horticultural Research station, Horticulture Research Institute, Agriculture Research Center, Egypt.
}

\begin{abstract}
The present investigation was carried out during the two summer seasons of 2015 and 2016 at sharnoob vilage, Damanhur city, Behera governorate, Egypt, to study the effect of foliar application of yeast extract, hydrogen peroxide $\left(\mathrm{H}_{2} \mathrm{O}_{2}\right)$ and combination of them on growth, yield and quality of sweet potato tuberous roots, using two sweet potato cultivars, Abees and Mabrouka. Generally, the results indicated that Abees cv. recorded maximum values of number of shoots/ plant in the second season, plant length in the first season, foliage fresh weigh/ plant, total sugar \%, reducing sugar $\%$, carotene $\%$, dry matter $\%$ and starch $\%$ contents of roots. Results showed also that spraying of yeast extract gave the highest means values for all studied traits of vegetative characters of two cultivars; in both seasons. Moreover, spraying of yeast extract gave the highest significant means values for total yield of roots/plant, weight of marketable roots/plant, number of marketable roots/plant, total sugar $\%$, reducing sugar $\%$, carotene $\%$, dry matter of roots $\%$ and starch $\%$ contents in roots compared with other treatments in both seasons. The treatment combination of growing Abees cultivar and yeast extract recorded the highest mean values of the most studied characters compared with other treatments.
\end{abstract}

Keywords: sweet potato, yeast extract, hydrogen peroxide.

\section{INTRODUCTION}

Sweet potato(Ipomoea batatas L.) is a very popular vegetable crop and is considered an important source of carbohydrates, vitamins A and C, fiber, iron, potassium and protein (Woolf, 1992). There are several sweet potato cultivars in Egypt such as Mabrouka cv., Abess cv. and 17-8 cvs. .ect. It has been cultivated as table food, as well as, recently the new hybrid progenies Kafer- EL Zayat and Beauregard cvs. (The International potato center 2006).

Dry yeast extract is a natural bio- substance suggested having stimulating, nutritional and protective functions when used on vegetables. Used of yeast extract was found to increase growth, yield and quality of many vegetable crops (Abou EL-Nasr et.al. 2001). In this regard, yeasts have been suggested to be enriched source of phytohormones (especially cytokinins), vitamins, enzymes, amino acids and minerals (Barnett et.al., 1990; Fathy and Farid, 1996; Khedr and Farid, 2002 and Mahmoud, 2001). It was additionally announced about its stimulatory impact on cell division and expansion, protein and nucleic acid synthesis as well as chlorophyll formation (Castel -franco and Beale, 1983). It is a natural bio substance contains many nutrient elements and productive compounds of semi growth regulator compound like auxins, gibberellins and cytokinins. It is use as soil fertilization or as foliar application of vegetable crops (El-Ghamriny et al., 1999). Hussain and Khalaf (2007) reported that using yeast extract increased the vegetative growth characters, yield/ plant, tubers dry matter percentage and total soluble solid (TSS). Ahmed et al., (2011) shown that expanding of foliar utilization of active dry yeast concentration expanded the vegetative growth characters, productivity and quality of potato tubers.

Romero and Delgado (2009) noted that hydrogen peroxide $\left(\mathrm{H}_{2} \mathrm{O}_{2}\right)$ and antioxidants had positive effect in enhancing potato tuber yield and quality. Mousa et.al., (2012) showed the presence of significant differences between the various concentration of $\mathrm{H}_{2} \mathrm{O}_{2}$ on potato dry matter their results showed that spraying the concentration of $40 \mathrm{mM} \mathrm{H}_{2} \mathrm{O}_{2}$ gave the highest percentage of tuber dry matter compared to the other concentrations, followed by spraying concentrations of 60 and $20 \mathrm{~m} \mu$, respectively.

Therefore, the present investigation was designed to disclose the influence of active dry yeast extract, $\mathrm{H}_{2} \mathrm{O}_{2}$ and the combination between them on vegetative growth, yield and quality of two cultivars of sweet potato.

\section{MATERIALS AND METHODS}

The present investigation was carried out during the two summer seasons of 2014 and 2015at Sharnoob village, Damanhur city, Behera governorate, Egypt, to study the effect of foliar application of yeast extract and hydrogen peroxide $\left(\mathrm{H}_{2} \mathrm{O}_{2}\right)$, as well as combination of them on growth, yield and quality of two sweet potato cultivars; Abess and Mabrouka. Table (1) shows the physical and chemical properties of the soil field.

The cutting were planted on May $29^{\text {th }}$ for both seasons. The plot area was $22.5 \mathrm{~m}^{2}$ (3 rows, $0.75 \mathrm{~m}$ in width and $10 \mathrm{~m}$ length with spacing of $25 \mathrm{~cm}$ between the cutting). 
Table 1: Physical and chemical analysis of the experimental site before starting the experiment.

\begin{tabular}{|c|c|}
\hline \multicolumn{2}{|l|}{ Saturated soil extract } \\
\hline $\mathrm{pH}$ & 7.85 \\
\hline $\mathrm{EC}, \mathrm{ds} / \mathrm{m}$ & 1.60 \\
\hline $\mathrm{CaCO}_{3}, \%$ & $2.37 \%$ \\
\hline $\mathrm{CEC}, \mathrm{meq} / \mathrm{kg}$ & 31.80 \\
\hline \multicolumn{2}{|l|}{ Soluble anions(meq/l) } \\
\hline $\mathrm{Ca}^{++}$ & 5.45 \\
\hline $\mathrm{Mg}^{++}$ & 5.16 \\
\hline $\mathrm{Na}^{+}$ & 10.4 \\
\hline $\mathrm{K}^{+}$ & 0.22 \\
\hline \multicolumn{2}{|l|}{ Soluble anions(meq/l) } \\
\hline HCO3- & 8.46 \\
\hline CL- & 1.66 \\
\hline SO4-- & 11.40 \\
\hline \multicolumn{2}{|l|}{ Particle size distribution (\%) } \\
\hline Sand & 38.7 \\
\hline Silt & 21.8 \\
\hline Clay & 39.5 \\
\hline Soil texture & Clay Loam \\
\hline $\begin{array}{l}\text { The experimental layout was a split -plot, in } \\
\text { randomized complete blocks design with three } \\
\text { replicates. The main plot was sweet potato cultivars. } \\
\text { The sub- plots consisted of three treatments; one } \\
\text { concentration of hydrogen peroxide }\left(\mathrm{H}_{2} \mathrm{O}_{2}\right) 60 \mathrm{~m} \mu \text {, } \\
\text { one concentration of yeast extract was prepared } \\
8 \text { grame from brewer 's yeast (Saccharomyces } \\
\text { cerevisiae), dissolved in } 1 \text { litter of water, } \\
\text { combination between them (spray yeast extract in } \\
\text { the first and follow that spray } \mathrm{H}_{2} \mathrm{O}_{2} \text { respectively), }\end{array}$ & $\begin{array}{l}\text { 2-Weight of marketable roots/plant } \\
\text { 3-Total number of roots/plant } \\
\text { 4-Number of marketable roots/plant } \\
\text { 3-Tuberous root quality: } \\
\text { 1- Dry matter }(\%) \text { : was determined by weighing a } \\
\text { random sample of fresh roots and then dried at } \\
70 c^{\circ} \text {. } \\
\text { Dry matter } \%=\frac{\text { dry weight }}{\text { fresh weight }} \times 100\end{array}$ \\
\hline
\end{tabular}
and control (spray with tap water).

Dry yeast extract, $\mathrm{H}_{2} \mathrm{O}_{2}$ and combination between them were sprayed to the plants at 30 days from planting up to 120 days every 14 days. The spraying was carried out early in the morning.

The chemical analysis of dry yeast extract, was protein $(47.2 \%)$ arginine $(2.6 \%)$, glycine $(2.6 \%)$, histidine $(1.4 \%)$, isolysine $(2.9 \%)$, leucine $(3.5 \%)$, carbohydrate, sugars, protein, fatty acids, amino acids, hormones, macro and microelements in suitable balance, Khedr and Farid (2002).

The normal culture practices were carried out according to the recommendation of the ministry of agriculture. The following data were recorded.

\section{Recorded measurements:}

\section{Vegetative growth characters:}

The following growth attributes were measured, 100 days after planting, using ten random plants from each treatment; plant length $(\mathrm{cm})$, number of shoots/plant and foliage fresh weight (gm./plant) as well as foliage dry matter $\%$.

\section{2-Tuberous root yield and its components:}

At harvest time, 130 days after planting, samples of ten random plants were harvested from each plot to record the following data; 1 -Total yield of roots/plant (gm.)

2- Carotene percentage (\%) of the roots was determined according to methods described by Arnon (1949).

3- Reducing and total sugars \% was determined by Dubios et al. (1956).

4- Tuber starch (\%) was determined according to the method by A.O.A.C. (1970).

\section{Statistical procedures:}

Collected data of the experiments were statistically analyzed according to Snedecor and Cochran (1980). Means separation was done using LSD at $5 \%$ level of probability

\section{RESULTS AND DISCUSSION}

\section{A- Vegetative Growth Characters:}

Data presented in Table 2 show that the cultivar Abees surpassed Mabrouka cultivar for all studied traits of vegetative characters except number of shoot/ plant and foliage dry matter in the first season and plant length in the second season. The detected differences on the vegetative growth characters of the two tested cultivars could be related to their genetic features.

The effect of foliar spraying of yeast, $\mathrm{H}_{2} \mathrm{O}_{2}$ and their combination on the vegetative growth characters of sweet potato plants are presented in table 2 . 



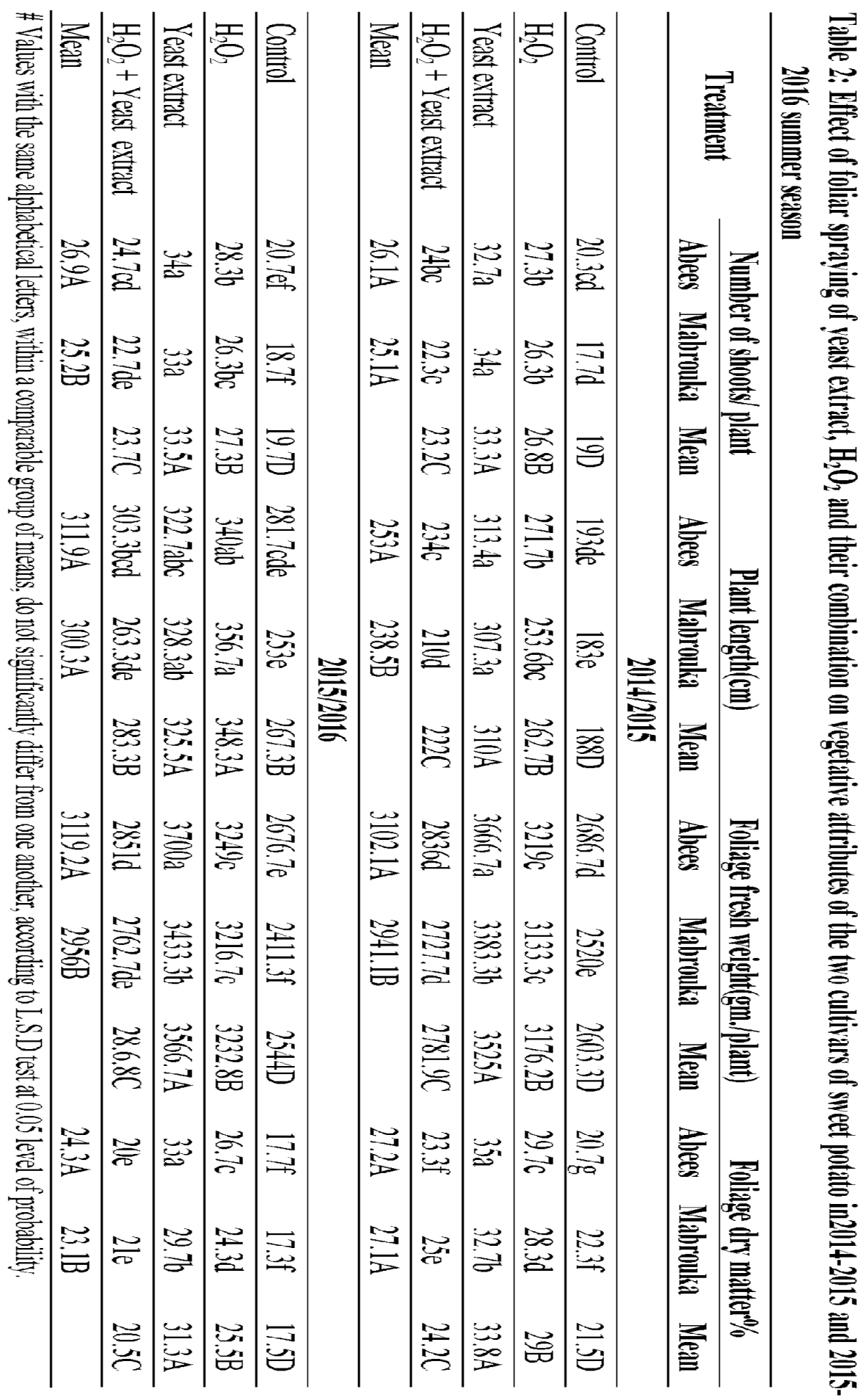



Spraying of yeast extract gave the highest means values for all studied traits of vegetative growth characters of sweet potato cultivars; in both seasons. However there are no significant differences between spraying of $\mathrm{H} 2 \mathrm{O} 2$ or yeast extract regarding plant length in the second season.

Regarding the interaction between treatments and cultivars data show that there are a significant differences for all studied traits of vegetative characters in both seasons. The significant effects of dry yeast extract could be due to providing a natural source of cytokinins that motivate cell division and enlargement as well as the formation of protein, nucleic acid and chlorophyll (Castelfranco and Beale, 1983 and Fathy and Farid, 1996.

The improvement of vegetative growth characters in response to the foliar application of active dry yeast extract may be attributed to its content of different nutrients, higher values of proteins, vitamins especially B which may play an important role in improving growth and controlling the incidence of fungi diseases (Meyer and Phaff, 1969 ), Sarhan and Abdullah, (2010) found that the positive effects caused by the addition of yeast suspension in improving shoots characteristics might be due to the development of the yeast after its analysis into wide groups of amino acids and vitamins. The obtained results are in accordance with those reported by Gomaa et al. (2005) on potato; Hussain and Khalaf, (2007); Likewise, Sarhan and Abdulah, (2010), found that the application of yeast suspension caused gradual significant increase in plant height, number of aerial stem per plant, leaves area, total chlorophyll, and shoots dry matter $\%$ of potato. It is known that yeast is considered as a natural source of cytokinins that stimulate cell division and enlargement as well as the synthesis of proteins, nucleic acids and chlorophyll (Fathy and Farid, 1996).

Moussa et.al. (2012) reported that there was no significant effect of the concentrations of $\mathrm{H} 2 \mathrm{O} 2$ on plant height and number of branches /plant during the two years of study. Reactive oxygen species (ROS) such as superoxide anions $\left(\mathrm{O}^{2-}\right)$, hydrogen peroxide $\left(\mathrm{H}_{2} \mathrm{O}_{2}\right)$, and hydroxyl radicals $\left(\mathrm{OH}^{-}\right)$are long considered as causing oxidative damage to lipids, proteins and nucleic acids, increasing evidence indicates that they also function as signaling molecules in plants, notably acting as regulators of growth and development, programmed cell death (Mittler et. al, 2004).

\section{B- Yield:}

The results in Table 3 show that root dry matter $\%$, other yield characters i.e. total yield of roots, weight of marketable roots/ plant, total number of roots /plant and number of marketable roots/ plant were insignificant as a results on two cultivars tested.
Concerning spraying of yeast extract gave the highest means values for total yield of root/plant, weight of marketable root/plant and root dry matter $\%$ in both seasons. However, total number of root/plant did not significantly affected by any treatment in the first season, but, in the second season, the highest significant mean value was obtained by spraying of yeast extract or $\mathrm{H}_{2} \mathrm{O}_{2}$ followed by their combination compared with control. The highest significant means values for number of marketable root/plant were obtained by spraying yeast extract or $\mathrm{H}_{2} \mathrm{O}_{2}$ in both seasons.

Regarding the effects interaction between treatments and cultivars data show that there are significant differences in both seasons. The treatment combination of growing Abees cultivar and yeast extract recorded the highest mean values of the most yield characters. Similar results were recorded by Ahmed et. al., (2011) they support the fact that, the use of dry yeast extract as a foliar spray leads to an increase of plant growth which causes significant increases in tubers weight per plant and total tubers yield of potato plant. Increasing number of tubers could be due to disturbance of plant hormones involved in tuber formation (Fernie and Willnitzer, 2001). On the other hand, Delgado et.al., (2005) showed that mean weight and number of tubers per plant were not found to be significantly differed under the different $\mathrm{H}_{2} \mathrm{O}_{2}$ concentration. Ghoname et.al., (2010) noticed that foliar application of yeast increased growth, yield and quality of sweet pepper.

\section{c- Roots quality:}

Data in Table 4 show that Abees cv. surpassed Mabruoka cv. for all tuber roots quality studied traits in both seasons. There was significant variation in total carotene contents between the two cultivars of sweet potato. This difference may be due to orange color of Abees compared with Mabroka. That is agreed with Mulokozi, (2003) who observed that the amount of total carotenoid contents differed with cultivars and the deeper the orange colour the more the carotenoid content.

Regarding to foliar spraying treatments yeast extract give the highest mean value of starch content, total sugar, reducing sugar and carotene tuber roots content during both seasons. This result agree with Hussain and Khalaf (2007) found that spraying yeast solution treatments significantly increased dry matter percentage of tubers and total soluble sugar (TSS). They add that tubers quality in terms of starch and dry matter showed positive responses to various yeast concentrations. ELTohamy et.al., (2015) indicated that T.S.S. of sweet potato were significantly improved especially by the high concentration of yeast. 



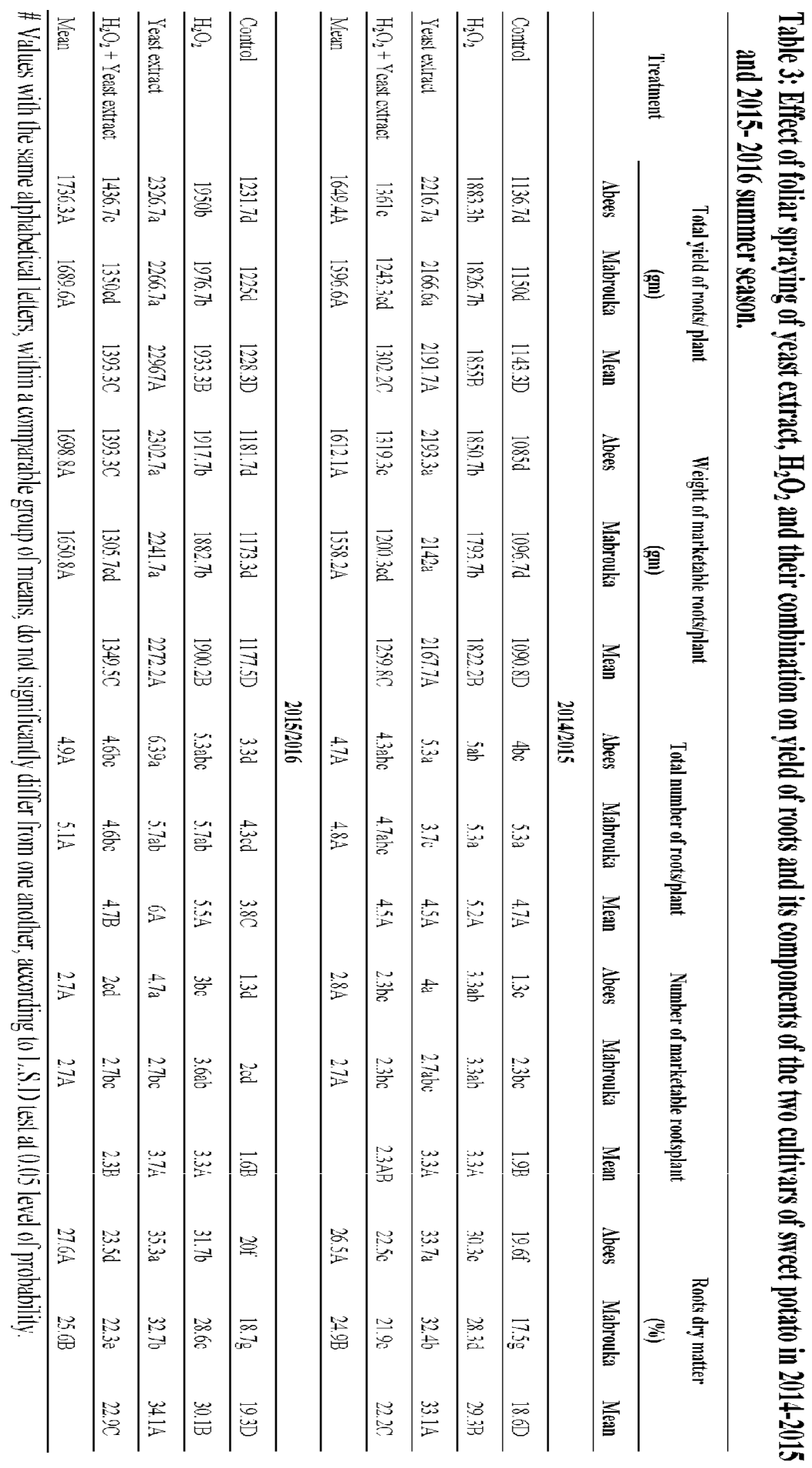




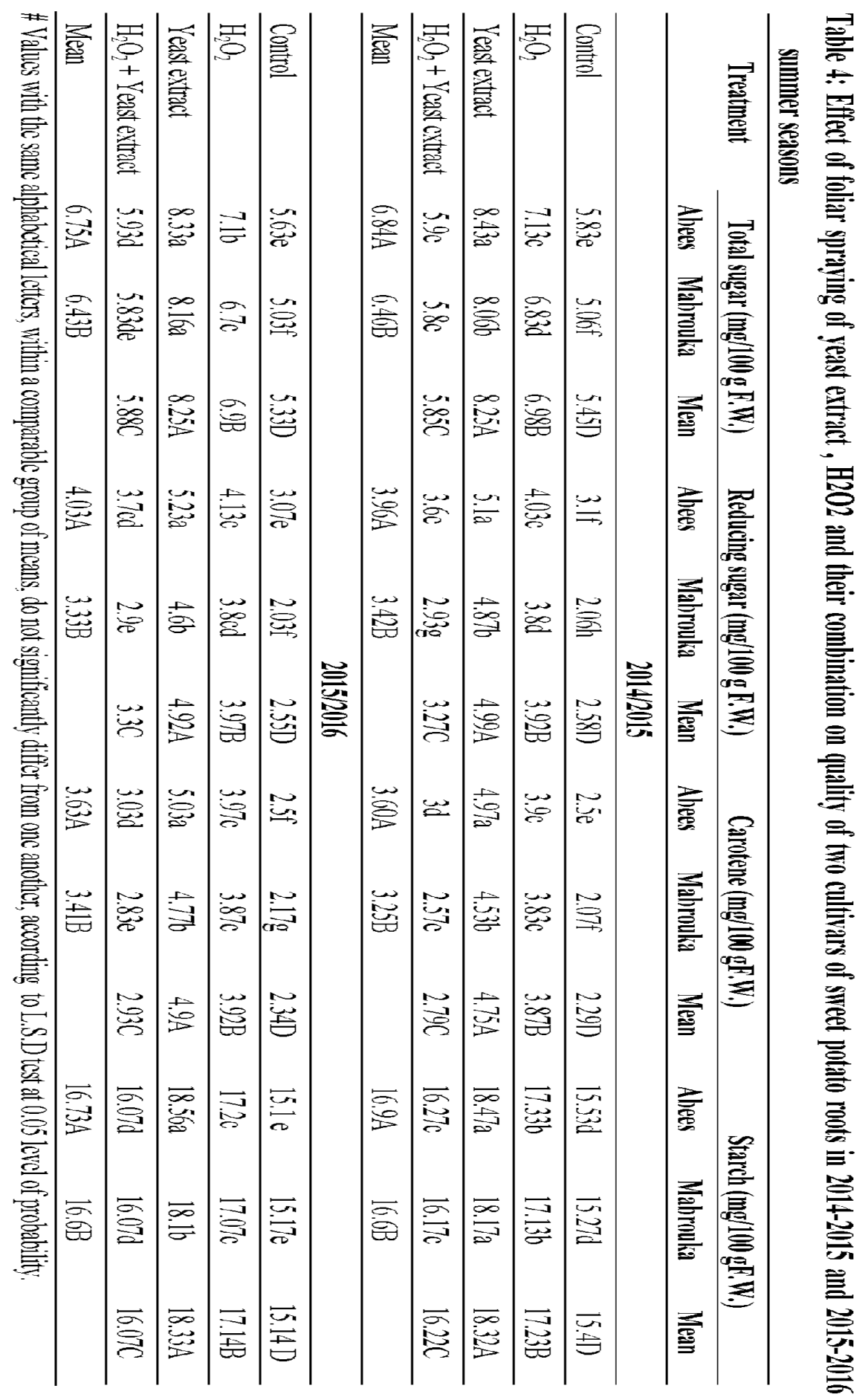


On the other hand, Delgado et. Al., (2005) clearly appeared that there was significance increasing of tuber starch percentages ranged from 6.7 to 30 as a result of spraying potato plants twice weekly with 5 or $50 \mathrm{Mm} \cdot \mathrm{H}_{2} \mathrm{O}_{2}$. Mousa et.al., (2012) found that there were no significant differences between different concentrations $(0,20,40,60 \mathrm{mM})$ of $\mathrm{H} 2 \mathrm{O} 2$ on the status of total sugars during the two seasons. Also there was no significant effect of the concentrations of $\mathrm{H} 2 \mathrm{O} 2$ on the status of reducing sugars content during the first season only.

Regarding the interaction between treatments and cultivars data show that there are significant differences for all tuber roots quality in both seasons. Generally, spraying yeast extract with Abees cv. treatment give a significant effect on tuber root quality i.e. total sugar, reducing sugar, carotene and starch content of roots in both season.

\section{REFERENCE}

Abou EL-Nasr, M.E., R. A. EL-Shabrawy and M.M.Abd EL-Rahm an.(2001). Effect of bread yeast application and some nutrient elements on squash (cucurbita pepo L.) plant growth,yield and fruit quality under conditions of the early summer planting. J.Agric. Sci. Mansoura Univ., 26 (7):4451-4464.

Ahmed,A.A., M.M.H.Abd EL-Baky, M.F.Zaki and FatenS.Abd EL-Aal (2011). Effect of foliar application of active yeast extract and zinc on growth, yield and quality of potato plant. J. of App. Sci., Res.,7(12): 2479-2488.

Arnon, D. I.(1949). Copper enzymes in isolated chloroplasts polyphenol oxidase in (Beta Vulgaris). Plant Physico. 24:1-15.

A.O.A.C. (1970). Official Methods of Analysis. Association of Official Analytical Chemists, Washington, D.C. 820pp.

Barnett, J.A.,R.W.Payne and D. Yarrow (1990). Yeasts, characteristics and Identification. Cambridge University Press, London,pp:999.

Castelfranco,P.A. and S.I. Beale (1983). Chlorophyll biosynthesis recent advances and areas of current increst Ann. Rev. Plant Physio., 34:241-278.

Delgado, L., H.A.Z. Mancera, Herrera ,M.V.Rivera, F.X.F. Gutierrez and L.M. Scott (2005). Hydrogen peroxide increases potato tuber and stem starch content, stem ciameter and stem lignin content. Amer. J. Potato Res. p.367-71.

EL-Ghamriny, E.A.,M.M.E.Arisha and K.A.Nour (1999). Studies in tomato flowering fruit set yield and quality in summer seasons spraying with thiamine, ascorbic acid and yeast. Zagazig J.Agric.Res., 26(5):1345-1364.
ELTohamy,W.A.,H.M.EL-Abagy, M.A.Badr, S.D. Abou-Hussein,Y.I.Helmy and M.R. Shafeek (2015). Effect of yeast extract and $\mathrm{GA}_{3}$ on water status,growth,productivity and quality of sweet potato grown in sandy soils. Int. J. Envir. Vol:40/Issue:04/Oct-Dec./pages:256-261.

Fathy, S.L. and S.Farid (1996). The possibility of using vitamin B and yeast to delay senescence and improve growth and yield of common beans (Phaseolus Vulgaris L) J. Agric. Sci. Mansoura Univ., 21(4):1415-1423.

Fernie A.R., L. Willmitzer (2001). Molecular and biochemical triggers of potato tuber development. Plant Physiol 127: 1459-1465.

Ghoname, A.A., M.A. EL-Nemr, A.M.R.AbdelMawgoud and W.A.EL-Tohamy (2010). Enhancement of sweet pepper crop growth and production by application of biological, organic and nutritional solutions. Res. J. of Agric and Biol. Sci., 6(3):349-355.

Gomaa, A.M., S.S. Moawad, I.M.A. Ebadah and H.A. Salim (2005). Application of bio-organic farming and its influence on certain pests infestation, growth and productivity of potato plants. J. of App. Sci. Res., 1(2): 205-211.

Hussain, W. and L. Khalaf (2007). Effect of foliar spraying with yeast solution on growth and yield of potato plant cv.desoree. Retrieved from:www.tropentage.de/2007/abstracts/Links /khalaf.FPRAXY90.

International Potato Center (CIP) (2006). Sweet potato production in Egypt, Book Home Association for printing and publishing. The International Potato Center, Kafr EL-Zayat. (In Arabic) 26p.

Khedr, Z.M.A. and S. Farid (2002). Response of naturally virus infected tomato plants to yeast extract and phosphoric acid application. Annals Agric. Sci. Mashtohor. Egypt, 38(2): 927-939.

Mahmoud, T.R. (2001).Botanical studies on growth and germination of Magnolia (Magnolia grandiflora L.) Plants. M.Sc Thesis, Fac. Agric., Moshtohor, Zagazig Univ.,103pp.

Meyer, S.A. and H.J. Phaff (1969). Deoxyribonucleic acid liase composition in yeasts. J. Bacterial, 97: 52-56.

Mittler R, S Vanderauwera, M Gollery, F. Van Breusegem (2004). Reactive oxygen gene network of plants. Trends Plant Sci 9: 490-498.

Moussa, S.A.M., N.I.Abo El-Fadl and N.F.Agamy (2012). Role of hydrogen peroxide in improving potato tuber quality. Alex. Sci. Exchange J.,33 (2). 
Mulokozi, G.I. (2003). Content and In Vitro accessibility of provitaminA carotenoids in some Tanzania vegetables and fruits. Effects of processing and preparation, and influence on vitamin A status. Thesis for Award of $\mathrm{PhD}$ at Chalmers University of Technology, Goteborg, Sweden, 165pp.

Remero,R.M.T. and H.A.L.Delgado (2009). Ameliorative effects of hydrogen peroxide, ascorbate and dehydroascorbate in solanium tuberosum infected by phytoplasma. Ameri. J. potato Res.,Vol.86:218-226.
Sarhan, T. and O.K. Abdullah (2010). Effect of Azotobacter Inoculation, Dry Bread Yeast Suspension and Varying Levels of Urea onGrowth of Potato Cv. Desiree. html/www.tropentage.de/2010/abstracts/full/62 8.

Snedecor, G.H. and W.C. Cochron (1980). Statistical methods $.7^{\text {th }}$ ed. Iowa State Univ, press. Ames, Iowa, USA.

Woolfe, J.A. (1992). Sweet potato: An untapped food resource. Cambridge University press, New York. Pp.643.

\section{تأثير اللش بطستخلص الخميرة وفوق لٔسيد الهيدوجين عل المحصرل وصفل الجوةفي البطابl}

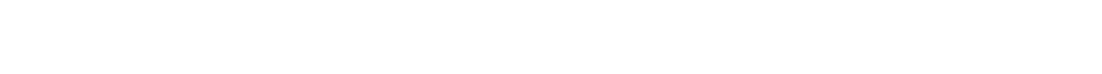

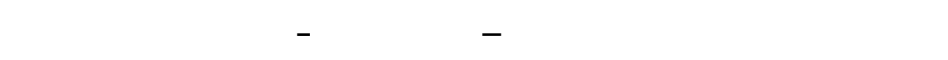

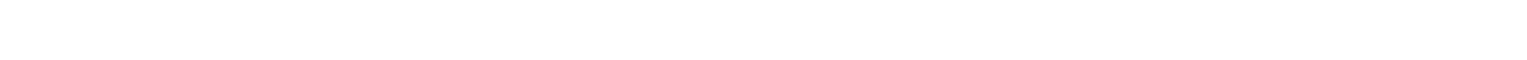
بمحلظة البحيرة لدرلسة تأثير الرش بمستخلص الخميرة النظطة وبيروكسيد الهيدروجين ومزيج بينهما عل مى نم -و

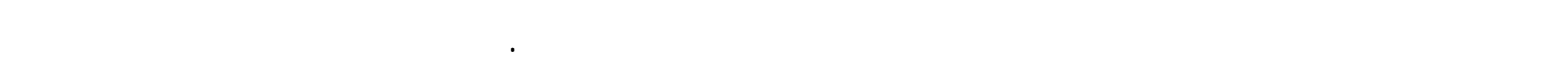

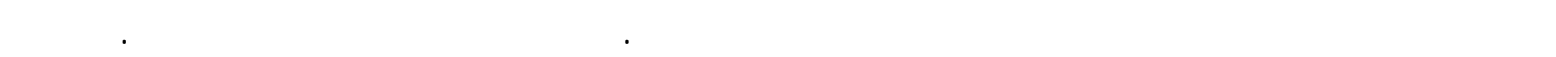

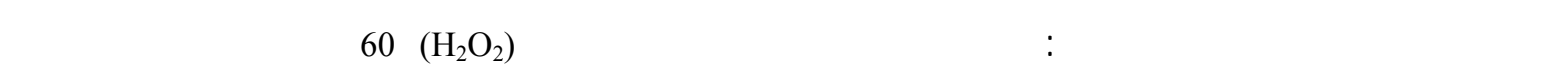
من مستخلص الخميرة الجلفة النثطة ^ جم/ لتر، ومزيج من بيروكسيد الهيدروجين + مستخلص الخمي -رة الذ شطة والكنترول (الرش بماء الصنبور)

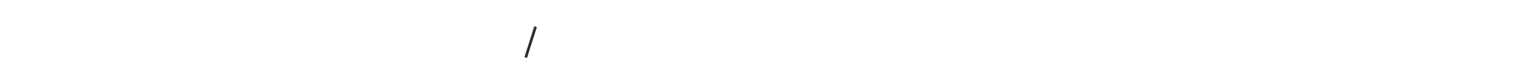

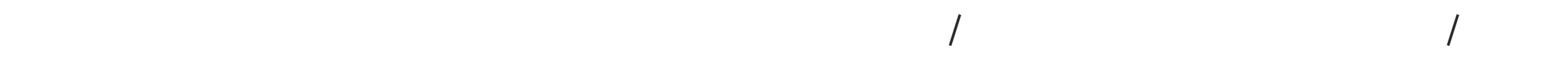

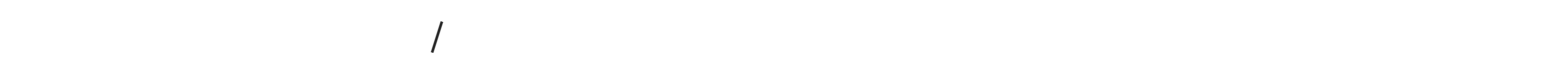
للتسويق / النبت في كلا الموسمين. وقد أوضحت الدرلسة أن تأثير الرش بطستخلص الخميرة أعطى أعلى قيم لجمبع ال ـصفلت المدروس ـة للا صفلت

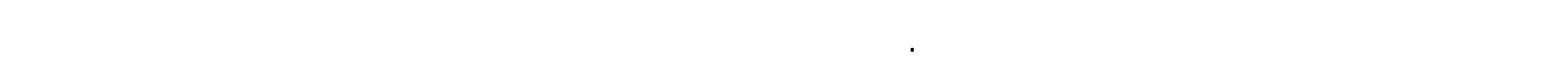

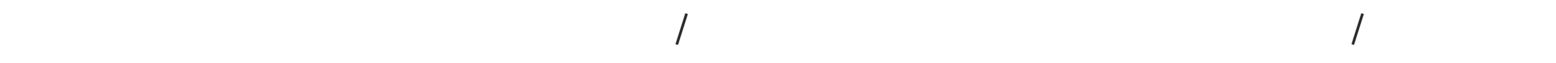
والمختزلة والكاروتين والمادة الجافة للجذور والنشا بالمقارنة بالمعلملات الأخرى في كلا الموسمين. وبصفه علمهسل الصف أبيس والصف مبروكة مع الرش بمستخلص الخميرة أعلى القيم للك من عدد الفروع للنبت والمحصول الكلى للجذور بالنبة للنبت ووزن الجذور الصالحة للتسويق وعدد الجذور الكلية للنبت والم الة الجلفة للجذور بالنبة للمعلملات الأخرى. 